\title{
Cantinoa althaeifolia essential oil: chemical composition and biological, antioxidant, antimicrobial, and antitumor activities
}

\author{
Composição química e atividades biológica, antioxidante, antimicrobiana e antitumoral do óleo \\ essencial de Cantinoa althaeifolia
}

Composición química y actividades biológicas, antioxidantes, antimicrobianas y antitumorales del aceite esencial de Cantinoa althaeifolia

\author{
Amanda Migliorini Urban \\ ORCID: https://orcid.org/0000-0001-6805-1603 \\ Universidade Federal do Paraná, Brazil \\ E-mail: amandamurban@yahoo.com.br \\ Juliane Nadal Dias Swiech \\ ORCID: https://orcid.org/0000-0002-5106-9767 \\ Universidade Federal do Paraná, Brazil \\ E-mail: juliswiech@yahoo.com.br \\ Gustavo Simão Moraes \\ ORCID: https://orcid.org/0000-0003-0777-5012 \\ Universidade Estadual de Ponta Grossa, Brazil \\ E-mail: moraes.gustavo29@yahoo.com.br \\ Katia Paludo \\ ORCID: https://orcid.org/0000-0003-2248-5881 \\ Universidade Estadual de Ponta Grossa, Brazil \\ E-mail: katiapaludo@gmail.com \\ Carmen Antonia Sanches Ito \\ ORCID: https://orcid.org/0000-0002-4786-1508 \\ Universidade Estadual de Ponta Grossa, Brazil \\ E-mail: itocar@uol.com.br \\ Josiane de Fátima Gaspari Dias \\ ORCID: https://orcid.org/0000-0002-8548-8505 \\ Universidade Federal do Paraná, Brazil \\ E-mail: josianefgdias@gmail.com \\ Deise Prehs Montrucchio \\ ORCID: https://orcid.org/0000-0003-1440-7007 \\ Universidade Federal do Paraná, Brazil \\ E-mail: deisepm@yahoo.com.br \\ Obdulio Gomes Miguel \\ ORCID: https://orcid.org/0000-0002-2231-9130 \\ Universidade Federal do Paraná, Brazil \\ E-mail: obdulio@ufpr.br \\ Marilis Dalarmi Miguel \\ ORCID: https://orcid.org/0000-0002-1126-9211 \\ Universidade Federal do Paraná, Brazil \\ E-mail: marilisdmiguel@gmail.com
}

\begin{abstract}
The species of the Lamiaceae family produce essential oils in the glandular trichomes, leaf surfaces, and in inflorescences, and can also produce many secondary compounds, which indicates great potential for study. The aim of this paper was to describe the chemical composition and the biological, antioxidant, antimicrobial, and antitumor activities of the essential oil of Cantinoa althaeifolia for the first time. The essential oil was obtained from the leaves by hydrodistillation and analyzed by gas chromatography mass spectrometry (GC/MS). The antioxidant activity was established by the phosphomolybdenum method. The minimum inhibitory concentration against Staphylococcus aureus, Escherichia coli, Pseudomonas aeruginosa, and Candida albicans was determined. The lethality test of Artemia salina was performed. The cytotoxicity against murine fibroblasts (3T3), non-tumor cells (McCoy), murine melanoma (B16F10), and human breast carcinoma (MCF-7) cells was assessed. Five major compounds were isolated: himachalene (11.62\%), spathulenol (10.08\%), caryophylline oxide $(9.93 \%)$, (E)-caryophylene $(9.21 \%)$, and pogostol $(6.31 \%)$. The phosphomolybdenum complex method showed positive results. The minimum inhibitory concentration was greater than $1000 \mu \mathrm{g} / \mathrm{mL}$ for the tested microorganisms. The mortality rate of Artemia salina was low. The tested
\end{abstract}


cancer cell lines showed an IC50 of 12.5 and $25 \mu \mathrm{g} / \mathrm{mL}$. These findings indicate that the essential oil of Cantinoa althaeifolia has antioxidant, antimicrobial, and antitumor activities.

Keywords: Lamiaceae; Plant oils; Microbial sensitivity tests; Phytogenic antineoplastic agents; Antioxidants.

\section{Resumo}

As espécies da família Lamiaceae produzem óleos essenciais nos tricomas glandulares, superfícies foliares e em inflorescências, podendo também produzir diversos compostos secundários, o que indica grande potencial de estudo. O objetivo deste trabalho foi descrever a composição química e as atividades biológica, antioxidante, antimicrobiana e antitumoral do óleo essencial de Cantinoa althaeifolia pela primeira vez. O óleo essencial foi obtido das folhas por hidrodestilação e analisado por cromatografia gasosa e espectrometria de massas (CG/EM). A atividade antioxidante foi determinada pelo método do fosfomolibdênio. A concentração inibitória mínima contra Staphylococcus aureus, Escherichia coli, Pseudomonas aeruginosa e Candida albicans foi determinada. Foi realizado o teste de letalidade de Artemia salina. A citotoxicidade contra fibroblastos murinos (3T3), células não tumorais (McCoy), melanoma murino (B16F10) e células de carcinoma de mama humano (MCF-7) também foi avaliada. Cinco compostos principais foram isolados: himachaleno (11,62\%), espatulenol (10,08\%), óxido de cariofileno $(9,93 \%)$, (E)-cariofileno (9,21\%) e pogostol (6,31\%). O método do complexo de fosfomolibdênio apresentou resultados positivos. A concentração inibitória mínima foi superior a $1000 \mu \mathrm{g} / \mathrm{mL}$ para os microrganismos testados. A taxa de mortalidade de Artemia salina foi baixa. As linhas de células cancerosas testadas mostraram uma CI50 de 12,5 e $25 \mu \mathrm{g} / \mathrm{mL}$. Esses achados indicam que o óleo essencial de Cantinoa althaeifolia possui atividades antioxidante, antimicrobiana e antitumoral.

Palavras-chave: Lamiaceae; Óleos vegetais; Testes de sensibilidade microbiana; Antineoplásicos fitogênicos; Antioxidantes.

\section{Resumen}

Las especies de la familia Lamiaceae producen aceites esenciales en los tricomas glandulares, la superficie de las hojas y las inflorescencias, y también pueden producir muchos compuestos secundarios, lo que indica un gran potencial de estudio. El objetivo de este trabajo fue describir la composición química y las actividades biológicas, antioxidantes, antimicrobianas y antitumorales del aceite esencial de Cantinoa althaeifolia por primera vez. El aceite esencial se obtuvo de las hojas por hidrodestilación y se analizó mediante cromatografía de gases y espectrometría de masas (CG/EM). La actividad antioxidante se estableció mediante el método del fosfomolibdeno. Se determinó la concentración mínima inhibitoria contra Staphylococcus aureus, Escherichia coli, Pseudomonas aeruginosa y Candida albicans. Se realizó la prueba de letalidad de Artemia salina. Se evaluó la citotoxicidad contra fibroblastos murinos (3T3), células no tumorales (McCoy), melanoma murino (B16F10) y carcinoma de mama humano (MCF-7). Se aislaron cinco compuestos principales: himachaleno (11,62\%), espatulenol (10,08\%), óxido de cariofileno (9,93\%), (E)-cariofileno $(9,21 \%)$ y pogostol $(6,31 \%)$. El método del complejo de fosfomolibdeno mostró resultados positivos. La concentración inhibitoria mínima fue superior a $1000 \mu \mathrm{g} / \mathrm{mL}$ para los microorganismos probados. La tasa de mortalidad de Artemia salina fue baja. Las líneas celulares de cáncer probadas mostraron una CI50 de 12,5 y 25 $\mu \mathrm{g} / \mathrm{mL}$. Estos hallazgos indican que el aceite esencial de Cantinoa althaeifolia tiene actividades antioxidantes, antimicrobianas y antitumorales.

Palabras clave: Lamiaceae; Aceites vegetales; Pruebas de sensibilidad microbiana; Antineoplásicos fitogénicos; Antioxidantes.

\section{Introduction}

The Lamiaceae family comprises about 240 genera and 7200 species, with a cosmopolitan distribution (Raymond Harley \& Pastore, 2012). These species grow mainly in open places, in almost all types of habitats and at all altitudes, from the Arctic to the Himalayas, from Southeast Asia to Hawaii, from north to south in the New World, and in Australia and Africa as well. The Mediterranean and Central Asia are the regions with the highest concentration of species (Heywood \& Royal Botanic Gardens, 2007). In Brazil, there are 34 native genera and about 496 species (Forzza et al., 2010).

The Lamiaceae family stands out for its economic importance, as it can be used for ornaments, cooking, or even as wood (RM Harley et al., 2009). Some plants can be used for culinary purposes, such as Ocium Basilicum L. (lavender), Orinagum vulvare L. (oregano), Mentha x piperita L. (peppermint), Mentha pulegium L. (pennyroyal), Rosmarinus officinalis L. (rosemary), Salvia officinalis L. (sage), and Thymus vulgaris L. (thyme); others can be used for making drinks, refreshments, or teas, including Melissa officinalis L. (lemongrass), Mentha spp. (mint), Salvia hispanica L. (blue sage), and Salvia splendens Sellow ex Roem. \& Schult. (Adam's blood); or for perfumery like Lavandula angustifólia Mill. (lavender) (Raymond Harley et al., 2004). 
Recently, essential oils have been receiving great interest due to their bioactive compounds, especially because of their antimicrobial, medicinal, antioxidant, cytostatic, and insecticidal properties (Tongnuanchan \& Benjakul, 2014). These oils are widely used as natural additives in foods and food products, for embalming and preserving food, and in the production of local anesthetics and antimicrobial, analgesic, sedative, anti-inflammatory, and spasmolytic remedies (Bakkali, Averbeck, Averbeck, \& Idaomar, 2008).

The species of the Lamiaceae family produce essential oils in the glandular trichomes, leaf surfaces, and in inflorescences, and can also produce many secondary compounds (Raymond Harley et al., 2004), which indicates great potential for study. The aim of this study was to describe the chemical composition of the essential oil of Cantinoa althaeifolia, and to evaluate its antimicrobial, antioxidant, and antitumor activities.

\section{Methodology}

This research was organized following the Scientific Research Methodology recommendations (Pereira et al., 2018).

\subsection{Plant material}

The botanical material was collected at the district of Boqueirão (coordinates $25^{\circ} 32^{\prime} 43^{\prime \prime} \mathrm{S}, 49^{\circ} 14^{\prime} 11^{\prime \prime} \mathrm{W}$ ), located in Curitiba, Paraná, Brazil, at $900 \mathrm{~m}$ of altitude, in February of 2017, 2018, and 2019. A specimen voucher was made and identified by the taxonomist Eraldo Barboza. The voucher was deposited in the Herbarium of the Botanical Museum of Curitiba, under registration $\mathrm{n}^{\circ}$ MBM 408166. This study was authorized by the Brazilian Institute of the Environment and Renewable Natural Resources (IBAMA) and registered at the National System for the Management of Genetic Heritage and Associated Traditional Knowledge (SisGen).

\subsection{Essential oil obtention}

The essential oil was obtained from $600 \mathrm{~g}$ of dried leaves, ground in a knife mil, hydrodistilled for $6 \mathrm{~h}$ using modified Clevenger type apparatus. This process was repeated 3 times. The essential oil was stored in a sealed amber glass at $-18^{\circ} \mathrm{C}$ until subsequent analysis. The yield calculation was performed in milliliters $(\mathrm{mL} / \%)$ of essential oil per $100 \mathrm{~g}$ of the drug (ANVISA, 2010).

\subsection{Identification of essential oil constituents}

The characterization of chemical constituents of the essential oil of leaves of Cantinoa althaeifolia was carried out using gas chromatography, composed of gas chromatograph coupled to a Shimadzu® CGEM-QP 2010 Plus mass spectrometer (Shimadzu, Kyoto, Japan), with a Rtx-5MS capillary column (30m x $0.25 \mathrm{~mm}$ x $0.25 \mu \mathrm{m}$; Bellefonte, PA, USA).

The injector was set in splitless mode at $250^{\circ} \mathrm{C}$, and the interface and source of ions were set at $300^{\circ} \mathrm{C}$. The mass window was set between $\mathrm{m} / \mathrm{z} 40$ and $\mathrm{m} / \mathrm{z} 350$, using helium as the entrainment gas with a column pressure of 20 psi. The injection ramp started at $50^{\circ} \mathrm{C}$ and was kept for $5 \mathrm{~min}$. Then, the temperature was increased at a rate of $5^{\circ} \mathrm{C} / \mathrm{min}$ to a final temperature of $200^{\circ} \mathrm{C}$.

The chemical components of the oil were identified by comparing their mass spectra with the reference spectra, and by comparing their Kovat's index with those described in the literature (Adams \& Adams, 2001).

\subsection{Formation of the phosphomolybdenum complex method}

The formation of the phosphomolybdenum complex was performed (Prieto, Pineda, \& Aguilar, 1999). Solutions of butylated hydroxytoluene (BHT), ascorbic acid, and rutin at a concentration of $200 \mu \mathrm{g} / \mathrm{mL}$ in methanol and Tween $800.5 \%$ 
were used as control. Aliquots of $0.3 \mathrm{~mL}$ were added to $3 \mathrm{~mL}$ of the phosphomolybdenum reagent $(0.1 \mathrm{M}$ tribasic sodium phosphate $(28 \mathrm{~mL}), 0.03 \mathrm{M}$ ammonium solution of tetrahydrate molybdate $(12 \mathrm{~mL}), 3 \mathrm{M}$ sulfuric acid $(20 \mathrm{~mL})$ and water to make $100 \mathrm{~mL}$ ). The tubes were closed and taken to a water bath at $95^{\circ} \mathrm{C}$ for $90 \mathrm{~min}$. After cooling, the absorbances were obtained in 96-well microplates with round bottoms (TPP®; Techno Plastic Prod., Trasadingen, SH, Switzerland) by reading in the Multiskan FC spectrophotometer (Thermo Fisher Scientific, Waltham, MA, USA) at 695 nm. The antioxidant capacity of samples was expressed in relative antioxidant activity (AAR\%), as compared to the standards, using the equation: AAR\% = [(Sample Absorbance - White Absorption) / (Standard Absorbance - White Absorbance)] x 100.

\subsection{Minimum inhibitory concentration (MIC)}

\subsubsection{Microorganisms}

The antibacterial and antifungal activity was determined against the following microorganisms from the American Type Culture Collection (ATCC; Rockville, MD, USA): Staphylococcus aureus (ATCC 29213), Escherichia coli (ATCC 25922), Pseudomonas aeruginosa (ATCC 27853), and Candida albicans (ATCC 40175).

\subsubsection{Minimum inhibitory concentration in broth microdilution}

Microorganisms were seeded in potato medium and incubated at $37^{\circ} \mathrm{C}$ for $48 \mathrm{~h}$. The suspension of Candida albicans was prepared in physiological saline at a concentration of 1 - 5.0 x $106 \mathrm{CFU} / \mathrm{mL}$. Then, a 1:100 dilution was made in RPMI1640 with glucose $2 \%$ (Gibco/Invitrogen, Carlsbad, CA, USA) in order to achieve a concentration of $103 \mathrm{CFU} / \mathrm{mL}$, as recommended by The Clinical \& Laboratory Standards Institute (CLSI).

A stock solution of all the extracts, fractions, and sub-fractions was prepared at a concentration of $16,000 \mu \mathrm{g} / 5 \mathrm{~mL}$ in polysorbate. Aliquots of $100 \mu \mathrm{L}$ of RPMI-1640 with glucose $2 \%$ were added to the 96-well microplates. The following concentrations of the extracts, fractions, and sub-fractions were evaluated: $2000 \mu \mathrm{g} / \mathrm{mL}, 1000 \mu \mathrm{g} / \mathrm{mL}, 500 \mu \mathrm{g} / \mathrm{mL}, 250 \mu \mathrm{g} / \mathrm{mL}$, $125 \mu \mathrm{g} / \mathrm{mL}$, and $62.5 \mu \mathrm{g} / \mathrm{mL}$. The plates were incubated at $37^{\circ} \mathrm{C}$ for $24 \mathrm{~h}$.

\subsection{Lethality test of Artemia salina}

The toxicity assay designed for the lethality tests uses the brine shrimp Artemia salina. A saline solution at the concentration of $30 \mathrm{~g} / \mathrm{L}$ of sea salt at a $\mathrm{pH}$ of 9 was used for the hatching of Artemia salina cysts and for the preparation of dilutions (Meyer et al., 1982). The cysts were placed in the saline solution for $48 \mathrm{~h}$, under continuous aeration and exposure to daylight. The temperature was maintained between 27 and $30^{\circ} \mathrm{C}$ and the $\mathrm{pH}$ between 8 and 9 . The recipient was kept under illumination during the first hour.

After the hatching of the cysts, about 10 nauplii of Artemia salina were transferred to tubes containing the essential oil diluted in $0.5 \%$ of polysorbate 80 and saline solution at the concentrations of $75,200,500,750$ or $1000 \mu \mathrm{g} / \mathrm{mL}$. A positive control was prepared with saline solution and quinidine sulphate, and a saline solution with polysorbate 80 was used as a negative control. The assay was performed in triplicate. The tubes were incubated at $27-30^{\circ} \mathrm{C}$ for $24 \mathrm{~h}$, and the live and dead nauplii were counted by visual inspection.

\subsection{Cell culture}

Murine melanoma (B16F10), human breast carcinoma (MCF-7), murine fibroblast (3T3), and non-tumor cells (McCoy) were cultivated in RPMI medium 1640® supplemented with fetal bovine serum 10\% (Gibco/Invitrogen) and antibiotics ( $1 \%$ of penicillin/streptazine) in a $5 \% \mathrm{CO} 2,95 \%$ humidity, $37^{\circ} \mathrm{C}$ incubator. 


\subsubsection{Cytotoxicity assay}

The cytotoxicity of the essential oil was measured using the MTT [3-(4,5-dimethylthiazol-2-yl)2,5diphenyltetratozolium bromide] colorimetric assay to determine cell viability through mitochondrial activity. MTT is a water-soluble tetrazolium salt, which is converted to an insoluble purple compound known as formazan after cleavage of the tetrazolium salt by mitochondrial dehydrogenases (Mosmann, 1983).

McCoy, B16F10, and MCF7 cells (3 x 103 cells/well) were plated $24 \mathrm{~h}$ prior to exposure to Cantinoa althaeifolia oil for adherence, scattering, and stabilization of the cells on the plaque. The cells were then exposed to increasing oil concentrations $(0.84 \mu \mathrm{g} / \mathrm{mL}$ to $8.4 \mathrm{mg} / \mathrm{mL}$ in RPMI medium, supplemented with fetal bovine serum $10 \%$ and antibiotics for 72 h). Immediately prior to treatment, the solutions containing the oil and the culture medium were vigorously shaken using a vortex-type stirrer for at least $1 \mathrm{~min}$.

After the treatment period, the medium was replaced by a solution of MTT $(0.5 \mu \mathrm{g} / \mu \mathrm{L})$ for $2 \mathrm{~h}$ at $37^{\circ} \mathrm{C}$. The MTT solution was then replaced by isopropyl alcohol $(0.1 \mathrm{M} \mathrm{HCl})$ for solubilization of the formazan crystals, and the absorbance was read at $570 \mathrm{~nm}$. A sample with no treatment was used as a control and the cell viability of other groups was expressed as the percentages of the control.

\subsection{Statistical analysis}

The MIC values were submitted to ANOVA and Tukey's test at the 5\% significance level ( $\mathrm{p}<0.05)$. The results of the lethality test of Artemia salina were analyzed using the PROBIT test, which provided LC50 values with reliability of $95 \%$. The degree of toxicity was based on three classifications: low toxicity, LC50 $>500 \mu \mathrm{g} / \mathrm{mL}$; moderate toxicity, LC50 between 100 $\mu \mathrm{g} / \mathrm{mL}$ and $500 \mu \mathrm{g} / \mathrm{mL}$; and high toxicity, LC50.

The concentration that inhibited the mitochondrial dehydrogenases activity by 50\% (IC50) was calculated using the software GraphPad Prism, version 7.0 for Windows (GraphPad Software, La Jolla, CA, USA, www.graphpad.com), following a tutorial provided by GraphPad Software, Inc, accessed May 19, 2018. (https://www.graphpad.com/support/faq/how-todetermine-an-icsub50sub/).

The selectivity index (SI) of the essential oil was calculated by the IC50 ratio between the non-tumor (McCoy) and tumor (MCF-7 and B16F10) lines according to the formula: IC50 = (IC50 non-tumor cell line) / (IC50 tumor cell line).

\section{Results and Discussion}

The extract of the essential oil of Cantinoa althaeifolia was made from the leaves of the dried and crushed plant. The oil obtained had a yellowish color and a strong odor, similar to other species of the Lamiaceae family. The calculated yield on the dry material mass was $2.21 \%(\mathrm{v} / \mathrm{m})$, with a final volume of $3.2 \mathrm{~mL}$ of essential oil.

The chemical composition of the essential oil of the leaves is shown in Table 1. The major chemical constituents in order of abundance were himachalene (11.62\%), spathulenol (10.08\%), caryophyllene oxide (9.93\%), (E)-caryophyllene $(9.21 \%)$, and pogostol $(6.31 \%)$, as presented in Figure 1. Himachalene is of extreme interest because it has not yet been identified in the Lamiaceae family, and there is little information about this compound in the literature. Spathulenol is found in alcoholic beverages and reported in several families, especially in Lamiaceae. It has antimicrobial (Tadić et al., 2017), toxicity and antitumor (Rolim et al., 2017), antinociceptive and anti-inflammatory activities (Barreto et al., 2016). Caryophyllene oxide is widely used as a flavoring agent and is found in several families, including the one of interest. This compound has antiinflammatory, antioxidant, antibiotic, cytotoxic (Côté et al., 2017), and anti-parasitic properties (Abd El-Gawad, El-Amier, \& Bonanomi, 2018). (E)-caryophyllene has proven anticancer, antioxidant and antimicrobial actions (Estevam et al., 2017). Finally, pogostol presents antimicrobial activity (Côté et al., 2017). 
Research, Society and Development, v. 10, n. 2, e9910212040, 2021

(CC BY 4.0) | ISSN 2525-3409 | DOI: http://dx.doi.org/10.33448/rsd-v10i2.12040

Figure 1. Major components of the Cantinoa althaeifolia essential oil.

1

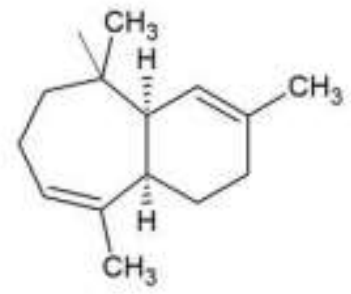

3
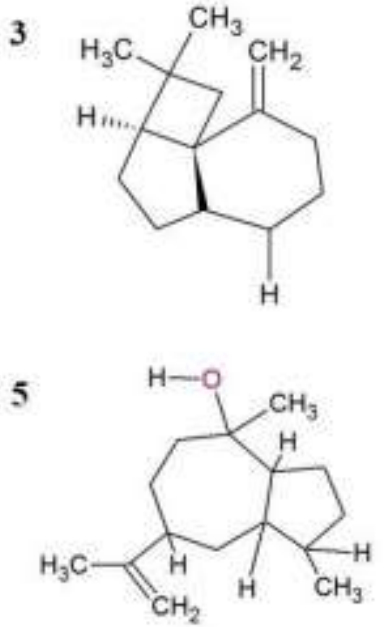

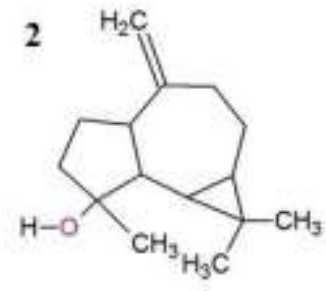

4<smiles>C=C1CC/C=C(/C)CC[C@H]2C[C@H]1C2(C)C</smiles>

* (1) himachalene, (2) spathulenol, (3) caryophyllene oxide, (4) (E)-caryophyllene, and (5) pogostol, Source: Authors (2020). 
Table 1. Chemical constitution of the essential oil from the leaves of Cantinoa althaeifolia.

\begin{tabular}{|c|c|c|c|}
\hline AI & $\mathbf{A I}_{\text {theoretical }}$ & Compound & {[]$\%$} \\
\hline 1020 & 1024 & Limonene & 1.94 \\
\hline 1036 & 1044 & (E)- $\beta$-Ocimene & 0.60 \\
\hline 1158 & 1174 & Terpinen-4-ol & 0.85 \\
\hline 1196 & 1215 & Carveol & 0.38 \\
\hline 1212 & 1239 & Carvone & 0.40 \\
\hline 1343 & 1350 & $\alpha$ - Longipinene & 1.10 \\
\hline 1364 & 1373 & $\alpha$-Ylangene & 0.33 \\
\hline 1369 & 1374 & $\alpha$-Copaene & 0.36 \\
\hline 1375 & 1387 & $\beta$-Bourbonene & 0.17 \\
\hline 1382 & 1389 & $\beta$-Elemene & 0.45 \\
\hline 1392 & 1400 & Sibirene & 0.43 \\
\hline 1402 & 1409 & $\alpha$-Gurjunene & 0.33 \\
\hline 1409 & 1417 & (E)- Caryophyllene & 9.21 \\
\hline 428 & 1439 & Aromadendrene & 1.73 \\
\hline 1436 & 1442 & 6,9 -guaiadiene & 0.50 \\
\hline 1441 & 1452 & $\alpha$-Humulene & 2.45 \\
\hline 1465 & 1478 & $\gamma$-Muurolene & 0.64 \\
\hline 1471 & 1481 & $\gamma$ - Himachalene & 11.62 \\
\hline 1473 & 1489 & $\beta$-Selinene & 0.48 \\
\hline 1483 & 1500 & Bicyclogermacrene & 3.48 \\
\hline 1488 & 1502 & Trans- $\beta$-Guaiene & 0.91 \\
\hline 1498 & 1500 & $\alpha$-Muurolene & 0.94 \\
\hline 1509 & 1522 & $\delta$-Cadinene & 1.94 \\
\hline 1520 & 1544 & $\alpha$-Calacorene & 0.32 \\
\hline 1557 & 1577 & Spathulenol & 10.08 \\
\hline 1561 & 1582 & Caryophyllene Oxide & 9.93 \\
\hline 1583 & 1608 & Humulene epoxide & 1.65 \\
\hline 1609 & 1627 & 1-epi-cubenol & 1.21 \\
\hline 1610 & 1632 & $\alpha$-acorenol & 0.38 \\
\hline 1613 & 1639 & Aromadendrene epoxide & 0.54 \\
\hline 1618 & 1635 & cis-Cadin-4-en-7-ol & 2.49 \\
\hline 1622 & 1636 & $\beta$-acorenol & 2.80 \\
\hline 1630 & 1651 & Pogostol & 6.31 \\
\hline 1645 & 1666 & 14-hidroxi-(Z) Caryophyllene & 3.43 \\
\hline 1657 & 1685 & Germacra-4(15),5,10(14)-trien-1- $\alpha$-ol & 0.91 \\
\hline 1690 & 1690 & $\begin{array}{l}\text { 6-isopropenyl-4,8a-dimethyl-1,2,3,5,6,7,8,8a-octahydro- } \\
\text { naftalen-2-ol }\end{array}$ & 0.54 \\
\hline
\end{tabular}


The antioxidant activity of the essential oil was calculated in relation to BHT, ascorbic acid, and rutin. Table 2 presents the results of the antioxidant activity by the phosphomolybdenum complexation method. The sample showed a characteristic green color, which demonstrates its antioxidant activity.

Table 2. Antioxidant activity of the Cantinoa althaeifolia essential oil.

\begin{tabular}{cccc}
\hline Sample & $\begin{array}{c}\text { Antioxidant activity in } \\
\text { relation to BHT }-\mathbf{A A} \\
(\%) \pm \text { SD }\end{array}$ & $\begin{array}{c}\text { Antioxidant activity in } \\
\text { relation to AAC }- \text { AA }(\%) \pm\end{array}$ & $\begin{array}{c}\text { Antioxidant activity in } \\
\text { relation to rutin - AA }(\%) \pm\end{array}$ \\
\hline BHT & $100^{\mathrm{a}}$ & SD & ----- \\
AAC & ---- & ----- & ---- \\
RUTIN & ---- & $100^{\mathrm{a}}$ & $100^{\mathrm{a}}$ \\
EO & $472.66 \pm 3.36^{\mathrm{h}}$ & ----- & $524.98 \pm 2.46^{\mathrm{g}}$ \\
\hline
\end{tabular}

BHT - butylated hydroxytoluene; AA - antioxidant activity; SD - standard deviation; AAC - ascorbic acid; and EO - essential oil. Data followed by same lower-case letters indicate not significant differences within columns ( $>0.05$, ANOVA and Tukey's test). Source: Authors (2020).

The essential oil of Cantinoa althaeifolia showed potential antimicrobial activity for the tested microorganisms. S. aureus, P. aeruginosa and C. albicans presented a MIC of $1000 \mathrm{mg} / \mathrm{mL}$, while E. coli presented a MIC of $500 \mathrm{mg} / \mathrm{mL}$. The bactericidal activity of sesquiterpenes like $\delta$-cadinene, $\alpha$-humulene, and karyophylene has been previously described (Pereira et al., 2017). However, when these substances were tested together, this activity were either reduced by competitive inhibition or improved because of the synergistic effect (Damasceno et al., 2018).

Artemia salina is a micro-crustacean easily found in specialized aquarium stores, that can used as live food for fish and to estimate toxicity by the average lethal concentration (LC50). This bioassay has been used in previous studies of plant extracts with possible antitumor activity and can be used for the initial assessment of a large number of samples for the evaluation of toxicity and phototoxicity. Several studies have attempted to correlate crustacean toxicity with antifungal, antimicrobial, parasiticidal, virucidal, and trypanosomicidal activities (Meyer et al., 1982). For the calculation of the LC ${ }_{50}$, the results were subjected to the Probit statistical test (Finney, 1971) and are presented in Table 3.

Table 3. Mortality rate of Artemia salina.

\begin{tabular}{ccccccccccccc}
\hline & \multicolumn{10}{c}{ Concentration $(\boldsymbol{\mu g} / \mathbf{m L}) /$ mortality $($ dead nauplii) } & $\begin{array}{c}\text { LC } \mathbf{5 0} \\
(\boldsymbol{\mu g} / \mathbf{m L})\end{array}$ & $\begin{array}{c}\text { IC 95\% } \\
(\boldsymbol{\mu g} / \mathbf{m L})\end{array}$ \\
& $\mathbf{5 0}$ & $\mathbf{7 5}$ & $\mathbf{1 0 0}$ & $\mathbf{1 2 5}$ & $\mathbf{1 5 0}$ & $\mathbf{2 0 0}$ & $\mathbf{5 0 0}$ & $\mathbf{7 5 0}$ & $\mathbf{1 0 0 0}$ & & - \\
\hline Essential oil & - & 1 & - & - & - & 1 & 3 & 3 & 4 & $>1000$ & $122.48-$ \\
Quinidine & 13 & 16 & 25 & 26 & 28 & - & - & - & - & 142.27 & 186.91
\end{tabular}

LC - lethal concentration; and IC - inhibitory concentration. (PROBIT test). Source: Authors (2020).

The cytotoxicity test results are presented in Figure 2. As shown in the first graph (1), the two initial concentrations tested (12.5 and $25 \mu \mathrm{g} / \mathrm{mL}$ ) for the MCF7 cell line were not statistically significant, and the IC50 value was 31.40 . For the B16F10 cell line (2), the IC50 was detected in the first concentration tested $(12.5 \mu \mathrm{g} / \mathrm{mL})$, with an IC50 value of 99.39. The 3 T3 cell line (3) was more resistant to the essential oil, showing an IC50 from the concentration of $50 \mu \mathrm{g} / \mathrm{mL}$, with an IC50 
value of 83.62. This cell line could be considered more selective in relation to this sample. The SI for the essential oil in the MCF7 and B16F10 cell lines was 2.66 and 0.84, respectively.

Figure 2. Viability of cell lines MCF7 (1), B16F10 (2), and 3T3 (3).
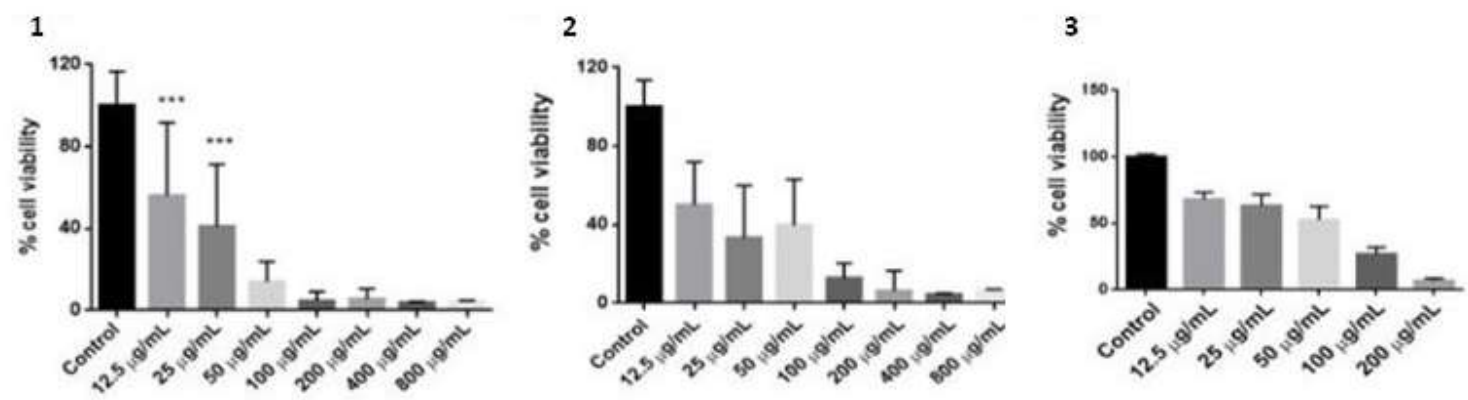

* Vertical bars represent mean $( \pm \mathrm{SD})$. Source: Authors (2020).

Figure 3 shows the morphological changes in the MCF7 cell line after being incubated with $50 \mu \mathrm{g} / \mathrm{mL}$ of the Cantinoa althaeifolia essential oil for $24 \mathrm{~h}$. It is possible to identify important morphological changes, such as chromatin condensation $(\mathbf{A})$, cell rounding $(\boldsymbol{-})$, and bubble formation $(\boldsymbol{\bullet})$. This is the first study to evaluate the cytotoxic activity of this essential oil. The root extract of Prunella vulgaris, a species also from the Lamiaceae family, reportedly has potent anticancer effects in MCF7 human BC cells both in vitro and in vivo, being able to induce apoptosis, inhibit angiogenesis, arrest cell cycle, and modulate the PI3K/AKT signaling pathway (Gao \& Xu, 2019). 
Figure 3. Morphological analysis of MCF7 cells.
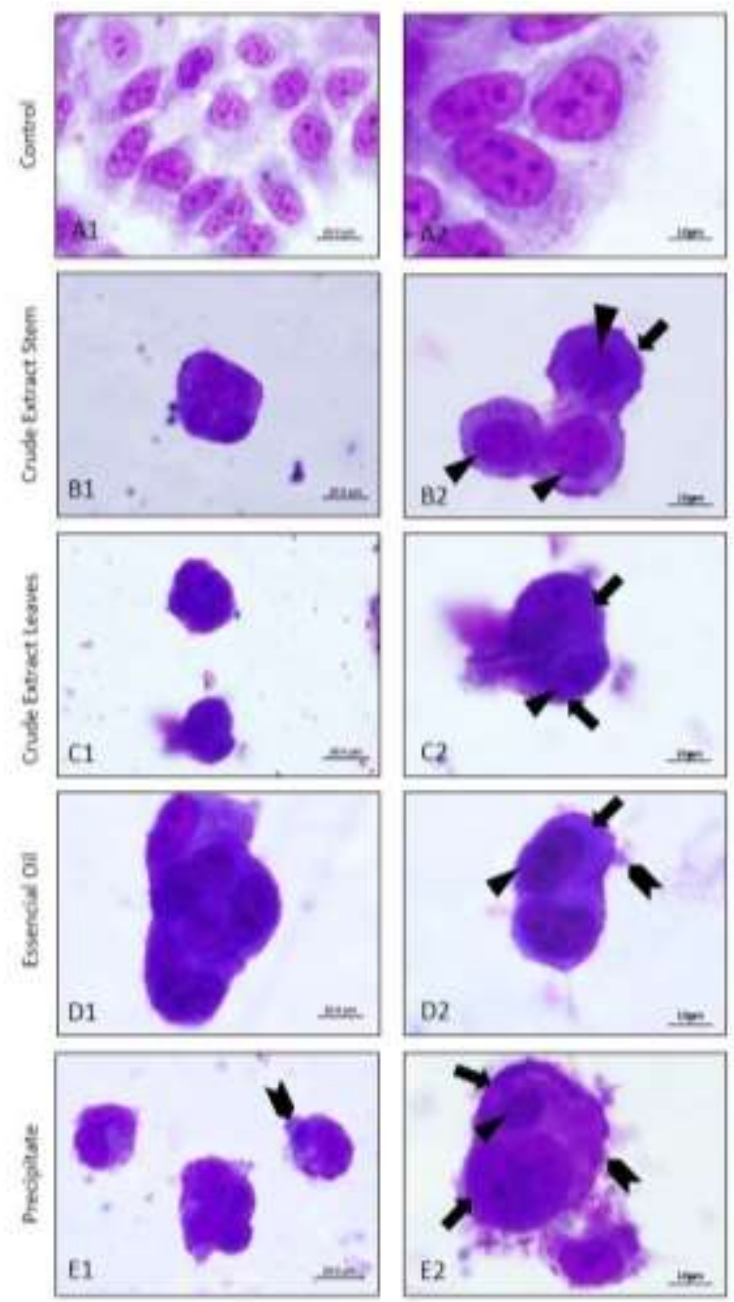

(Magnification: $1000 \mathrm{x}$ (left column) and $2000 \mathrm{x}$ (right column)).

*Chromatin condensation $(\mathbf{\Delta})$, cell rounding $(\boldsymbol{\bullet})$, and bubble formation $(\boldsymbol{\bullet})$.

Source: Authors (2020).

Figure 4 displays the morphological changes found in the murine melanoma tumor line, B16F10, after being incubated with $50 \mu \mathrm{g} / \mathrm{mL}$ of the Cantinoa althaeifolia essential oil for $24 \mathrm{~h}$. It is also possible to notice chromatin condensation $(\boldsymbol{\Delta})$, roundness $(\boldsymbol{-})$, and bubble formation $(\boldsymbol{-})$. Shakeri et al. (2019) tested the activity of Stachys parviflora, another species from the Lamiaceae family, against human ovarian carcinoma cells (A2780), human colon carcinoma cells (HCT), and mouse melanoma cells (B16F10), and also obtained a strong cytotoxic effect (Shakeri et al., 2019). 
Figure 4. Morphological analysis of B16F10 cells.
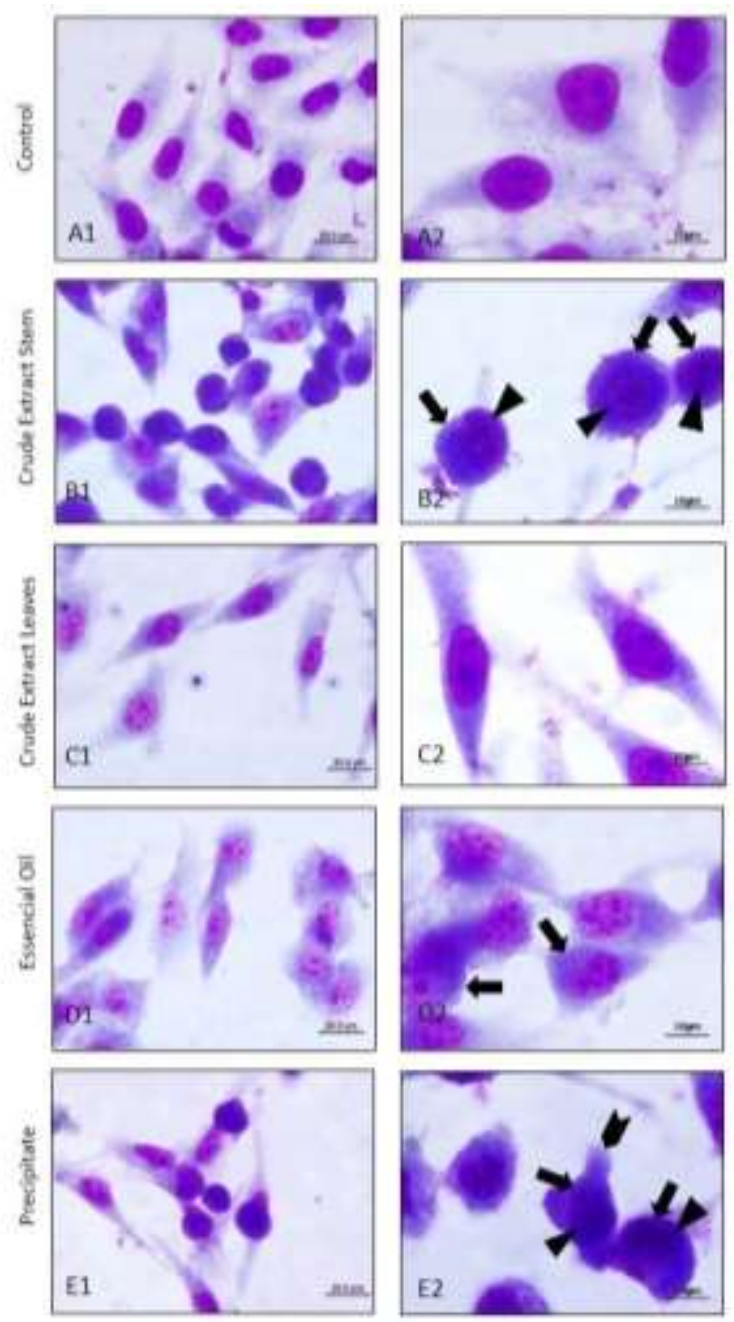

(Magnification: $1000 \mathrm{x}$ (left column) and $2000 \mathrm{x}$ (right column)).

*Chromatin condensation $(\boldsymbol{\Delta})$, cell rounding $(\boldsymbol{\bullet})$, and bubble formation $(\boldsymbol{\bullet})$. Source: Authors (2020).

Figure 5 presents the morphological changes found in non-tumor murine fibroblasts (3T3), after being incubated with $50 \mu \mathrm{g} / \mathrm{mL}$ of the essential oil of Cantinoa althaeifolia for $24 \mathrm{~h}$. Once again, it was possible to detect condensation of chromatin $(\boldsymbol{\Delta})$, cell rounding $(\boldsymbol{-})$, and possible apoptotic body $(\boldsymbol{\bullet})$. 
Figure 5. Morphological analysis of murine 3T3 fibroblasts.
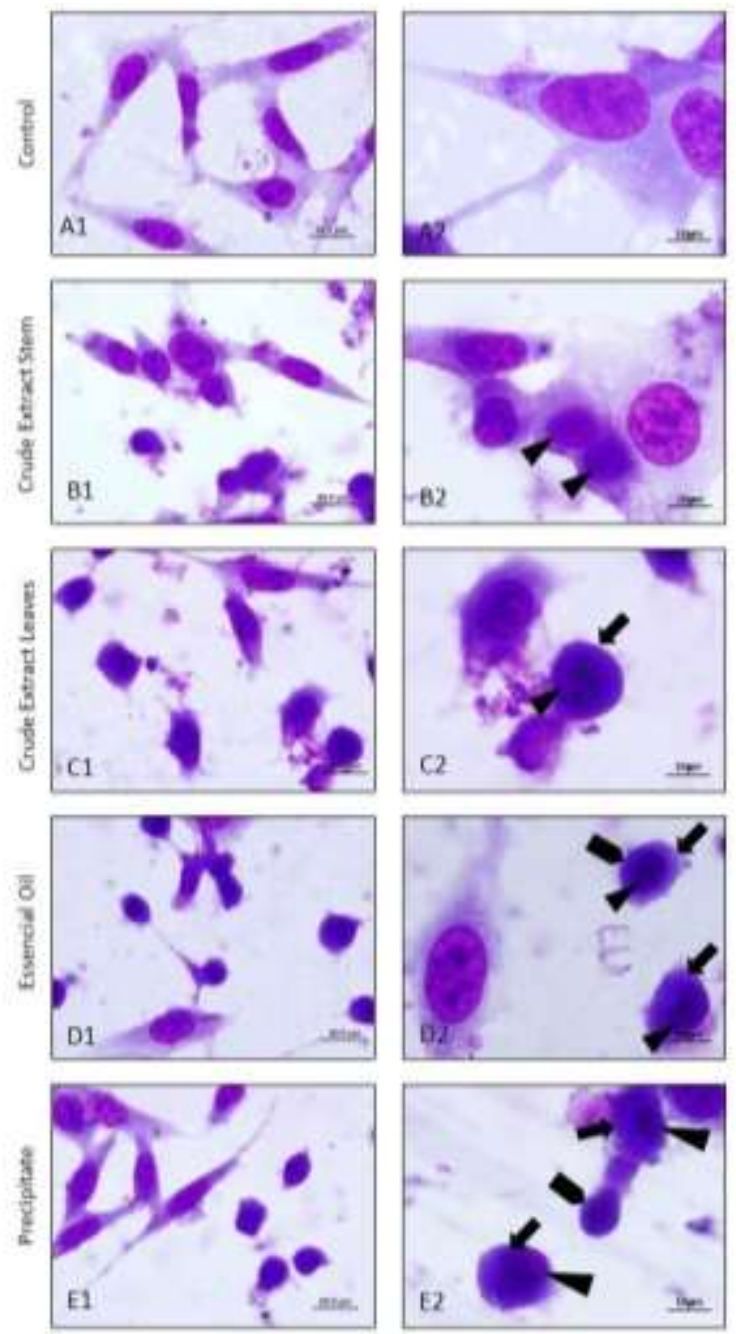

(Magnification: $1000 \mathrm{x}$ (left column) and $2000 \mathrm{x}$ (right column)).

$*$ Chromatin condensation $(\boldsymbol{\Delta})$, cell rounding $(\boldsymbol{-})$, and bubble formation $(\boldsymbol{\bullet})$.

Source: Authors (2020).

The findings from the lethality test of Artemia salina combined with the results from the cytotoxicity test with MTT are promising because they confirm that the oil is only toxic against the tumor cell lines. These findings corroborate with reports that oils with terpenes and sesquiterpenes in their chemical composition have antioxidant and antitumor activities (Morshedloo, Quassinti, Bramucci, Lupidi, \& Maggi, 2017).

The literature reports that some constituents found in the essential oil of Turkish Origanum onites, also from the Lamiaceae family, have activity against parasitic diseases (Tasdemir, Kaiser, Demirci, Demirci, \& Baser, 2019). According to Batisttini et al. (2019), the chemical constituents of the essential oils of several fruits from the Lamiaceae family have activity against the hepatitis A virus, and several of these constituents were found in the present study (Battistini et al., 2019).

\section{Conclusion}

Although there is no marked bactericidal activity, the Cantinoa althaeifolia essential oil has shown considerable antimicrobial activity against all the tested microorganisms, indicating that this plant can be a promising treatment for various infections.

The Cantinoa althaeifolia essential oil has cytotoxic activity against the tested cancer cell lines, especially against 
melanoma cells. The decrease in the number of cells, morphological changes, and increase in the sub-G0 phase may suggest that the mechanism involved in this effect may be related to apoptosis. The selectivity index showed that the tested samples were less toxic to blood cells, suggesting that this compound could be a promising drug in the treatment of melanoma and human breast cancer.

Further studies, especially in vivo, are necessary to confirm that this plant can be an alternative for enhancing antineoplastic therapy. The susceptivity of different microorganisms and different strains could also be an interesting field to explore in the future.

\section{Acknowledgments}

This work was supported by the Coordination for the Improvement of Higher Education Personnel - Brazil (CAPES) [finance code 001].

\section{References}

Abd El-Gawad, A. M., El-Amier, Y. A., \& Bonanomi, G. (2018). Allelopathic Activity and Chemical Composition of Rhynchosia minima (L.) DC. Essential Oil from Egypt. Chemistry \& Biodiversity, 15 (1).

Adams, R. P., \& Adams, R. P. (2001). Identification of essential oil components by gas chromatography, quadrupole mass spectroscopy. Illinois: Allured Publishing Corporation.

ANVISA. Agência Nacional De Vigilância Sanitária. (2010). Farmacopeia Brasileira. Editora Fiocruz.

Bakkali, F., Averbeck, S., Averbeck, D., \& Idaomar, M. (2008). Biological effects of essential oils--a review. Food and Chemical Toxicology, 46 (2), $446-475$.

Barreto, R. S. S., Quintans, J. S. S., Amarante, R. K. L., Nascimento, T. S., Amarante, R. S., Barreto, A. S., Pereira, E. W. M., Duarte, M. C., Coutinho, H. D. M., Menezes, I. R. A. Zengin, G., Aktumsek, A. Quintans-Júnior, L. J. (2016). Evidence for the involvement of TNF- $\alpha$ and IL-1 $\beta$ in the antinociceptive and anti-inflammatory activity of Stachys lavandulifolia Vahl. (Lamiaceae) essential oil and (-)- $\alpha$-bisabolol, its main compound, in mice. Journal of Ethnopharmacology, 191, 9-18.

Battistini, R., Rossini, I., Ercolini, C., Goria, M., Callipo, M. R., Maurella, C., Pavoni, E., Serracca, L. (2019). Antiviral Activity of Essential Oils Against Hepatitis A Virus in Soft Fruits. Food and Environmental Virology, 11 (1), 90-95.

Côté, B., Jiménez, D., Planquette, B., Roche, A., Marey, J., Pastré, J., Meyer, G., Sanchez, O. (2017). Prognostic value of right ventricular dilatation in patients with low-risk pulmonary embolism. The European Respiratory Journal, 50 (6).

Damasceno, C. S. B., Oliveira, L. F. d., Szabo, E. M., Souza, Â. M., Dias, J. F. G., Miguel, M. D., \& Miguel, O. G. (2018). Chemical composition, antioxidant and biological activity of Ocotea bicolor Vattimo-Gil (LAURACEAE) essential oil. Brazilian Journal of Pharmaceutical Sciences, 53 (4).

Estevam, E. B. B., Deus, I. P. B., Silva, V. P. D., Silva, E., Alves, C. C. F., Alves, J. M., Cazal, C. M., Magalhães, L. G., Pagotti, M. C., Esperandim, V. R., Souza, A. F. Miranda, M. L. D. (2017). In vitro antiparasitic activity and chemical composition of the essential oil from Protium ovatum leaves (Burceraceae). Anais da Academia Brasileira de Ciências, 89 (4), 3005-3013.

Finney, D. (1971). Probit Analysis. Press.

Forzza, R. C., Baumgratz, J. F. A., Bicudo, C. d. M., Carvalho Jr, A., Costa, A., Costa, D. P., Hopkins, M., Leitman, P. M., Lohmann, L. G., Maia, L. C. (2010). Catálogo de plantas e fungos do Brasil. Rio de Janeiro: Andrea Jakobsson Estúdio - Instituto de Pesquisas Jardim Botânico do Rio de Janeiro.

Gao, W., \& Xu, H. (2019). Root extract of Prunella vulgaris inhibits in vitro and in vivo carcinogenesis in MCF-5 human breast carcinoma via suppression of angiogenesis, induction of apoptosis, cell cycle arrest and modulation of PI3K/AKT signalling pathway. Journal of B.U.ON., 24 (2), 549-554.

Harley, R., Atkins, S., Budantsev, A., Cantino, P., Conn, B., \& Grayer, R. (2004). The Families and Genera of Vascular Plants. Berlin: Springer.

Harley, R., França, F., Giulietti, A., Rapini, A., Andrade, M., Queiroz, L., \& Silva, J. (2009). Plantas Raras do Brasil: Conservação Internacional. Belo Horizonte: Ministry of Environment of Brazil.

Harley, R., \& Pastore, J. F. (2012). A generic revision and new combinations in the Hyptidinae (Lamiaceae), based on molecular and morphological evidence. Phytotaxa, 58, 1-55.

Heywood, V. H., \& Royal Botanic Gardens, K. (2007). Flowering plant families of the world. Richmond: Royal Botanic Gardens, Kew.

Meyer, B. N., Ferrigni, N. R., Putnam, J. E., Jacobsen, L. B., Nichols, D. E., \& McLaughlin, J. L. (1982). Brine shrimp: a convenient general bioassay for active plant constituents. Planta Medica, 45 (5), 31-34.

Morshedloo, M. R., Quassinti, L., Bramucci, M., Lupidi, G., \& Maggi, F. (2017). Chemical composition, antioxidant activity and cytotoxicity on tumour cells of the essential oil from flowers of Magnolia grandiflora cultivated in Iran. Natural Product Research, 31, 1-8. 
Research, Society and Development, v. 10, n. 2, e9910212040, 2021

(CC BY 4.0) | ISSN 2525-3409 | DOI: http://dx.doi.org/10.33448/rsd-v10i2.12040

Mosmann, T. (1983). Rapid colorimetric assay for cellular growth and survival: application to proliferation and cytotoxicity assays. Journal of Immunological Methods, 65 (1-2), 55-63.

Pereira, F. G., Marquete, R., Domingos, L. T., Rocha, M. E. N., Ferreira-Pereira, A., Mansur, E., \& Moreira, D. L. (2017). Antifungal activities of the essential oil and its fractions rich in sesquiterpenes from leaves of Casearia sylvestris Sw. Anais da Academia Brasileira de Ciências, 89 (4), $2817-2824$.

Pereira, A. S., Shitsuka, D. M., Parreira, J. S., \& Shitsuka, R. (2018). Metodologia da pesquisa científica. Ed. UAB / NTE / UFSM. https://repositorio.ufsm.br/bitstream/handle/1/15824/Lic_Computacao_Metodologia-Pesquisa-Cientifica.pdf?sequence=1

Prieto, P., Pineda, M., \& Aguilar, M. (1999). Spectrophotometric quantitation of antioxidant capacity through the formation of a phosphomolybdenum complex: specific application to the determination of vitamin E. Analytical Biochemistry, 269 (2), 337-341.

Rolim, T. L., Meireles, D. R. P., Batista, T. M., de Sousa, T. K. G., Mangueira, V. M., de Abrantes, R. A., Pita, Jclr, Xavier, A. L., Costa, V. C. O., Batista, L. M., da Silva, M. S. Sobral, M. V. (2017). Toxicity and antitumor potential of Mesosphaerum sidifolium (Lamiaceae) oil and fenchone, its major component. BMC Complementary and Alternative Medicine, 17 (1), 347.

Shakeri, A., D'Urso, G., Taghizadeh, S. F., Piacente, S., Norouzi, S., Soheili, V., \& Salarbashi, D. (2019). LC-ESI/LTQOrbitrap/MS/MS and GC-MS profiling of Stachys parviflora L. and evaluation of its biological activities. Journal of Pharmaceutical and Biomedical Analysis, 168, 209-216.

Tadić, V., Oliva, A., Božović, M., Cipolla, A., De Angelis, M., Vullo, V., Garzoli, S., Ragno, R. (2017). Chemical and Antimicrobial Analyses of Sideritis romana L. subsp. purpurea (Tal. ex Benth.) Heywood, an Endemic of the Western Balkan. Molecules, 22 (9).

Tasdemir, D., Kaiser, M., Demirci, B., Demirci, F., \& Baser, K. H. C. (2019). Antiprotozoal Activity of Turkish Origanum onites Essential Oil and Its Components. Molecules, 24 (23).

Tongnuanchan, P., \& Benjakul, S. (2014). Essential oils: extraction, bioactivities, and their uses for food preservation. Journal of Food Science, 79 (7), R12311249 . 